\title{
LIMA STUDI KASUS DALAM ASAS KONFLIK KEPENTINGAN SERTA KESAMAAN ANTARA FIQIH DAN HUKUM
}

\author{
Khaled Alakeel \\ Alakeel Lawyers \& Legal Consultants \\ Attorney.ksa@gmail.com \\ DOI : https://doi.org/10.29313/shjih.v17i2.5502
}

\begin{abstract}
ABSTRAK
Dalam khazanah perkembangan hukum dan fiqih ditemukan beberapa konflik asas konflik kepentingan antara keduanya. Tulisan ini bertujuan untuk mengulas konflik kepentingan dan kesamaan antara hukum dan fiqh. Hasil pembahasan bahwa konflik kepentingan merupakan salah satu asas terpenting dalam hukum modern yang sering kita dengar mengenai aplikasinya pada berbagai bidang, seperti bidang ekonomi dan administratif. Setelah mengkaji dengan saksama dan meneliti lebih dalam kesimpulan yang bisa ditarik bahwa ini adalah asas penting. Bahwa asas ini berasal dan kembali kepada ketentuan Syariat karena ketetapan hukum Islam lama dipenuhi oleh ketentuan yang ketat dan akurat yang menentukan situasi konflik kepentingan dalam berbagai bidang, seperti jual-beli, sumpah, zakat, preemsi, dan perwakilan.
\end{abstract}

\section{Kata Kunci : Asas Konflik Kepentingan, Hukum dan Fiqih.}

\begin{abstract}
In the treasury of the development of law and jurisprudence, several conflicts were found based on conflicts of interest between the two. This paper aims to review the conflicts of interest and similarities between law and fiqh. The results of the discussion that conflict of interest is one of the most important principles in modern law that we often hear about its application in various fields, such as the economic and administrative fields. After studying carefully and examining in more conclusions that can be drawn that this is an important principle. That this principle originates and returns to Sharia provisions because the provisions of old Islamic law are met by strict and accurate provisions that determine situations of conflict of interest in various fields, such as buying and selling, oaths, almsgiving, preaching and representation.
\end{abstract}

Keywords: Principle of Conflict of Interest, Law and Fiqh. 


\section{A. PENDAhULUAN}

\section{Latar Belakang}

Islam mengatur semua kegiatan manusia termasuk dalam melakukan muamalah dengan memberikan batasan apa saja yang boleh dilakukan (Halal) dan apa saja yang tidak diperbolehkan (Haram). ${ }^{1}$ Perkembangan dan ekonomi dan perubahan hukum pada setiap bangsa tentunya melibatkan bangsa lain baik jauh maupun dekat jaraknya, langsung maupun tidak langsung. ${ }^{2}$ Ekonomi syariah sebagai salah satu sistem ekonomi nasional memerlukan berbagai sarana pendukung agar dapat memberikan konstribusi yang maksimum bagi pengembangan ekonomi nasional. Asas konflik kepentingan dianggap sebagai salah satu kaidah penting dalam hukum kontemporer. Asas ini berkaitan dengan seluruh kegiatan ekonomi, manajemen, dan yudisial serta aspek-aspek lain dalam dunia hukum.

Pentingnya asas ini terlihat dengan jelas dalam dua pilar yang menjadi dasarnya, pilar pertama yaitu pentingnya mencapai keadilan dengan menerapkan asas keseimbangan bagi semua sehingga tidak ada perbedaan antara satu orang dengan yang lain dalam hal pengetahuan atau kekuasaan yang dapat dimanfaatkan untuk mempengaruhi orang lain. Pilar kedua digambarkan sebagai pentingnya memperhatikan dan menjaga keadilan hukum, posisional, manajemen, atau yudisial yang bebas dari keraguan dan kecurigaan atas kemungkinan adanya prasangka yang memenangkan satu pihak atas pihak lain, suatu perkara yang akan menimbulkan ketidakadilan dalam keputusan serta peraturan yang dikeluarkan oleh badan hukum. Oleh karena itu, pihak yang bersangkutan dalam hal ini hendaknya mengundurkan diri apabila mereka meyakini adanya konflik kepentingan sebelum mempertimbangkan dan menetapkan

\footnotetext{
${ }^{1}$ Ira Puspitasari, Anaisis Praktik Etika Bisnis Syariah (Studi Kasus Pasar Leuwiliyang), Jurnal Amwaluna, Vol 3 No 1 Januari 2019, hlm 41

${ }^{2}$ Chaniur Arrasjid, Hukum Pidana Perbankan, Sinar Grafika, Jakarta, 2013, hlm 21
} 
atau mengambil keputusan apapun. Maka, tindakan ini merupakan langkah pencegahan berdasarkan peraturan yang berbunyi, "Melakukan langkah pencegahan demi menangkal kecurigaan.”. Eksistensi sebuah hukum pada dasarnya diwujudkan dalam rangka terciptanya tatanan kehidupan yang aman dan tenteram dalam kehidupan bermasyarakat. Hal itu berlaku juga dalam hukum Islam. Hukum Islam (syari'at Islam) mengandung tujuan untuk mewujudkan kemaslahatan dan kebaikan hidup yang hakiki bagi manusia, baik secara individual maupun sosial. Alquran sendiri sebagai sumber utama hukum. ${ }^{3}$

Konflik kepentingan adalah istilah yang digunakan untuk menggambarkan situasi dimana aparat publik atau aparat hukum berada dalam posisi yang memungkinkan untuk menyetujui atau mengeluarkan keputusan apapun, baik secara individu maupun kolektif, pro atau kontra terhadap pihak lain yang memiliki hubungan relasi, kerabat, atau kepentingan dalam hal apapun yang dapat memberi mereka keuntungan atau melindungi mereka dari ancaman atas nama kepentingan lembaga atau posisi yang diwakili. Oleh karena itu, jika seseorang merasakan adanya situasi konflik kepentingan, sebaiknya ia menjauhkan diri sementara dari kondisi tersebut sampai kasus selesai atau ia mengundurkan diri jika salah satu dari dua lembaga atau jabatan tersebut saling bertentangan pada satu sisi, serta permanen dan konstan disisi yang lain. Selain kecurigaan atau keraguaan yang berkenaan dengan salah satu dari dua posisi tersebut, atau jabatan dalam beberapa kasus, keputusan yang berdasar pada konflik kepentingan dapat dibatalkan atau dianggap tidak sah bahkan di kemudian hari.

\section{Identifikasi Masalah}

${ }^{3}$ Dudi Badruzaman, Hubungan Antara Moral dengan Hukum, Jurnal Syiar Hukum, Vol 16 No 1, 2017, hlm 41 
Beragam situasi konflik kepentingan terlihat dengan jelas dalam berbagai hukum dan syariat pada bidang ekonomi dan administratif disamping peraturan umum atau lazim yang dapat mencerminkan aplikasi praktis dari konflik kepentingan. Bagaimana lima studi kasus asas konflik kepentingan dan kesamaannya antara hukum dan fiqih?

\section{Metode Penelitian}

Metode penelitian dalam penulisan ini menggunakan pendekatan yuridis normatif karena mengkaji berbagai aturan dalam hukum Islam yang bersumber pada Al-Qur'an dan Hadits dengan menggunakan data sekunder berupa buku dan artikel yang relevan dengan persoalan yang dibahas.

\section{B. PEMBAHASAN}

\section{Konflik Kepentingan Dalam Transaksi Jual Beli}

Islam adalah agama yang rahmatan lil'alamin, yang menjadi rahmat bagai semesta alam. ${ }^{4}$ Kebebasan beragama atau berkeyakinan (kebebasan beragama) merupakan salah satu rumpun dalam hak asasi manusia (HAM) sebagaimana termaktub dalam Deklarasi Universal HAM (DUHAM). ${ }^{5}$ Ekonomi syariah sebagai salah satu sistem ekonomi nasional memerlukan berbagai sarana pendukung agar dapat memberikan konstribusi yang

${ }^{4}$ Hermansyah, Impementasi Bagi Hasil Dengan Prinsip Mudharabah Pada Bank Syariah di Indonesia Dihubungkan dengan Fatwa DSN No : 15/DS-MUI/IX/2000, Jurnal Mimbar Justitia, Vol 4 No 1, 2018, hlm 44

${ }^{5}$ Suparman Marzuki, Politik Hukum Hak Asasi Manusia Tentang Kebebsan Beragama Pasca Orde Baru, Jurnal Ius Quia Iustum, Vol 26 No 2, 2019, hlm 219 
maksimum bagi pengembangan ekonomi suatu negara, ${ }^{6}$ namun kerap ditemukan konflik norma antara hukum nasional dengan huum Islam. Ekonomi dan keuangan merupakan urat nadi dalam pembangunan suatu negara dan menentukan kelangsungan pembangunan suatu negara di masa yang akan datang. ${ }^{7}$ Rendahnya pertumbuhan ekonomi mengakibatkan rendah dan menurunnya tingkat kesejahteraan rakyat. ${ }^{8}$ Terdapat banyak kasus konflik kepentingan dalam kontrak jual beli. Yurisprudensi (Ketetapan Hukum) Islam berisi rujukan terhadap berbagai pendapat cendekiawan Muslim dan imam dari bermacam mazhab, seperti Hambali, Syafii, Hanafi, dan Maliki, yang berupaya mencegah kasus konflik kepentingan. Dapat anda lihat dibawah ini pendapat para cendekiawan Muslim ternama dalam bidang ini:

a) Imam Ahmad (bin Hambal) mengatakan: Pemimpin pasukan Muslim tidak diboleh membeli apapun dari barang rampasan tentara Muslim karena ia menyukainya, dan karena Khalifah Umar bin Khatab mengembalikan seluruh barang yang dibeli oleh beberapa orang dari invasi Jalola yang mengatakan bahwa beliau mungkin tidak adil, maka Imam Ahmad menggunakan Hadits ini sebagai dasar bahwa pemimpin pasukan bertindak sebagai penjual atau agen dari penjual. Oleh karena itu, ketika ia membeli barang rampasan perang seolah ia membeli dari dirinya sendiri atau menjadi agen atas dirinya sendiri. ${ }^{9}$

b) Wali amanat tidak diizinkan menjual atau membeli dari anak dibawah perwaliannya dari dan untuk dirinya sendiri, misalnya: wali amanat "membeli dan menjual dari uang milik anak tersebut oleh wali dari dan

${ }^{6}$ Ainun Najib, Kepastian Hukum Eksekusi dan Pembatalan Putusan Arbitrase Syariah dalam Perspektif Politik Hukum, Jurnal Ius Quia Iustum, Vol 26 No 3, 2019, hlm 566

${ }^{7}$ Adrian Sutedi, Hukum Keuangan Negara, Sinar Grafika, Jakarta, 2012, hlm 10

8 C.S.T. Kansil dan Christine Kansil, Hukum Keuangan dan Perbendaharaan Negara, Pradnya Paramita, Jakarta, 2008, hlm 216

${ }^{9}$ Al-Mughni, Ibnu Qudamah vol. 8 hlm. 447 
untuk dirinya sendiri tidak diperbolehkan menurut mayoritas cendekiawan Muslim, namun mazhab Hanafi membagi antara wali yang ditunjuk oleh hakim dan wali yang ditunjuk oleh ayah. Menurutnya wali yang ditunjuk oleh hakim tidak diperbolehkan membelikan sang anak barang dari dirinya atau menjual hartanya kepada anak tersebut. Akan tetapi, wali yang ditunjuk oleh ayah diperbolehkan membeli dan menjual harta anak tersebut. Menurut Abu Hanifa and Abu Yusuf, terdapat satu pepatah yang sesuai dengan salah satu pendapat dari mahzab Maliki, namun pendapat yang paling jelas, hal ini tidak diperbolehkan ${ }^{10}$.

"Wali tidak diizinkan bertransaksi untuk dirinya sendiri dari harta milik anak yatim," adalah sebagai berikut: Imam Hanafi dan Imam Maliki mengatakan tidak diizinkan seorang wali melakukan transaksi untuk dirinya sendiri dari uang milik anak yatim atau orang yang sudah meninggal, yang juga mirip dengan pendapat Imam Syafii dan Hambali ${ }^{11}$.

\section{Konflik Kepetingan Dalam Sumpah}

Contoh situasi konflik kepentingan yang tidak langsung termasuk diantaranya menyiapkan bukti untuk salah satu pihak lawan, dengan memberikan kesaksian atau mengambil sumpah dibawah hukum, jika bukti atau sumpah tersebut mengandung kepentingan orang yang disumpah. Dalam kasus seperti ini, kecurigaan adanya kepentingan pribadi dapat terlihat jelas dan akan mengurangi netralitas ketika memberi kesaksian atau bersumpah. Beberapa pendapat hukum termasuk pengertiannya sudah disebutkan dalam Jurnal Keputusan Pengadilan Syariah -buku yang berdasar pada pendapat Imam Ahmad bin Hambal, ditulis oleh hakim Ahmad bin Abdullah Al-Qari, mengandung kalimat sebagai berikut: "Tidak ada seorang pun yang boleh bersumpah dihadapan pengadilan untuk membuktikan hak orang lain jika ia berkepentingan secara langsung dalam kontroversi ini. Sebagai contoh, apabila orang yang pailit atau orang yang sudah meninggal mempunyai hutang kepada

${ }^{10}$ Ensiklopedia Ketetapan Hukum, Kementrian Wakaf Kuwait vol. 43 hlm. 194

${ }^{11}$ Sama dengan atas, hlm. 195 
saksi namun orang yang pailit atau ahli waris orang yang meninggal itu menolak bersumpah dengan saksi tersebut, maka pihak lawan pun tidak boleh bersumpah. Contoh lain, jika seseorang mempunyai hutang kepada salah satu saksi yang menolah untuk bersumpah, maka istrinya pun tidak boleh bersumpah karena tunjangan finansialnya berkaitan dengan kasus ini ${ }^{12}$."

\section{Konflik Kepentingan Dalam Pembayaran Zakat}

Aplikasi praktis dari konflik kepentingan dalam keputusan pengadilan Syariah terlihat dengan jelas dalam pembayaran Zakat, salah satu dari lima rukun Islam. Konflik kepentingan berdasarkan hadirnya kepentingan yang saling bertentangan dan menggambarkan dua sifat berbeda, adanya sifat-sifat tersebut secara bersamaan akan menyebabkan pelanggaran peradilan serta timbulnya ketimpangan dan kerugian. Untuk alasan inilah keberadaan konflik kepentingan tidak diperbolehkan dalam kondisi apapun, termasuk Zakat seperti dijelaskan dibawah ini:

Zakat merupakan kewajiban bagi setiap Muslim yang mampu dan kekayaannya mencapai jumlah yang dapat dikenai pajak, maka seorang Muslim wajib mengeluarkan Zakat atas hartanya kepada salah satu kelompok penerima Zakat sebagaimana disebutkan dalam surat At-Taubah ayat 60: Sesungguhnya zakat itu hanyalah untuk orang-orang fakir, orang miskin, amil zakat, yang dilunakkan hatinya (mualaf), untuk memerdekakan hamba sahaya, untuk (membebaskan) orang yang berhutang, untuk jalan Allah, dan orang yang sedang dalam perjalanan, sebagai kewajiban dari Allah. Allah Maha Mengetahui, Maha Bijaksana.

Muslim yang membayar Zakat mungkin memiliki kerabat tingkat pertama yang berhak menerima Zakat, seperti ayah dan kakek, serta anak dan cucu. Dalam hal ini pemberi Zakat wajib mengeluarkannya untuk mereka berdasarkan syariat Islam, meskipun beberapa kerabat tersebut mungkin

12 Jurnal Ketetapan Hukum Syariah (Majalat Alahkam Alshar'iyah), Ahmad bin Abdullah Al-Qari, Pasal 1239 hlm. 396 
termasuk golongan miskin dan membutuhkan yang berhak menerima Zakat menurut status ekonomi mereka. Jadi jika pemberi Zakat merupakan kerabat orang yang membutuhkan itu, maka ia tidak boleh memberikan Zakatnya kepada mereka menurut sebagian besar pendapat hukum Islam karena adanya keraguan bahwa Zakat yang dibayarkan akan kembali lagi kepada pemberi Zakat itu sendiri dan ia akan dianggap tidak membayar Zakat atau seperti membayar Zakat pada diri sendiri, karena ia bertanggung jawab mengeluarkan Zakat untuk keturunan dan leluhurnya atau siapapun yang wajib ia keluarkan Zakatnya. Ini berarti bahwa pemberi Zakat mengambil kembali jumlah yang telah ia bayarkan sebagai Zakat lalu kemudian ia belanjakan lagi untuk mereka dan dalam hal ini, pemberi Zakat akan dianggap seolah-olah ia menjadikan dirinya penerima Zakat dan membelanjakannya pada kerabat yang wajib ia keluarkan Zakatnya. Dibawah ini adalah beberapa contoh bukti hukum yang menunjukkan poin tersebut diatas:

\section{a. Pembayaran Zakat Untuk Anak dan Orang Tua}

Mengenai golongan yang tidak boleh diberi Zakat terangkum sebagai berikut:

Siapapun yang memiliki hubungan keluarga dengan pemberi Zakat, misalnya orang tua, seperti ayah, kakek, dan baik mereka yang berhak diberi dari warisan atau tidak, serta ia atau keturunannya, seperti anak, cucu dan seterusnya, mazhab Hanafi memberikan alasan mengapa (orang-orang ini) tidak boleh diberikan Zakat karena kelangsungan warisan harta diantara mereka (ini merupakan pendapat mazhab Hanafi dan mazhab Hambali) ${ }^{13}$. Syeikh Abdulaziz Alsalman dari Saudi menyatakan sebagai berikut:

Zakat tidak boleh dibayarkan pada orang tua dan diatasnya serta keturunan dan dibawahnya karena memberi Zakat pada mereka akan menghilangkan nafkah darinya dan manfaat dari Zakat yang dibayarkan akan kembali kepadanya karena ia memberi pada dirinya sendiri atau seolah-olah ia membayar hutangnya dari pemberian Zakat kecuali diberikan

${ }^{13}$ Ensiklopedia, vol. 23 hlm. 326 
kepada mualaf, Mujahid (dalam perang suci melawan orang kafir), orang yang berhutang, atau yang mendamaikan antara pihak yang bertikai. Dalam Buku Koleksi Perkara Hukum, penulis menyebutkan bahwa Zakat boleh diberikan kepada orang tua dan anak cucu jika mereka miskin namun ia tidak dapat menafkahi mereka karena adanya alasan ini, ini juga salah satu dari dua pendapat Imam Ahmad bin Hambal.

Ma'n bin Yazid mengisahkan: "Kakekku, ayahku, dan aku sendiri berjanji setia kepada Rasulullah. Rasul mengkhitbahkan dan menikahkanku. Suatu hari aku mendatangi Rasul untuk mengadu. Ayahku Yazid telah mengambil beberapa koin emas untuk sedekah dan menyimpannya dengan seorang laki-laki di masjid (untuk diberikan kepada orang miskin). Ayahku berkata, "Demi Allah! Aku tidak bermaksud memberikannya padamu. "Aku membawa kasus ini kepada Rasulullah. Untuk itu Rasulullah bersabda, "Wahai Yazid! Kau akan diberi ganjaran atas apa yang kau niatkan. Wahai Fulan! Apapun yang sudah kau ambil adalah milikmu."

Ibnu Rajab Al Hambali mengatakan bahwa pemberian Zakat kepada anaknya tidak dapat diterima karena khawatir dianggap sebagai pilih kasih, namun jika Zakat itu sampai kepadanya secara tidak sengaja meskipun yang menerima layak diberi Zakat, maka tidak ada lagi pilih kasih dan tindakan ini diperbolehkan ${ }^{14}$. Pemberian Zakat kepada anak: Para cendekiawan hukum Islam telah sepakat bahwa Zakat tidak boleh diberikan oleh pemberi Zakat kepada anaknya karena kelangsungan warisan harta ${ }^{15}$.

\section{b. Pembayaran Zakat Kepada Istri}

Konsep yang sama juga diterapkan dalam pembayaran Zakat kepada istri karena suami secara hukum berkomitmen untuk menafkahi istrinya sehingga jika ia memberinya Zakat sang istri akan membelanjakan Zakat itu untuk dirinya daripada nafkah yang seharusnya menjadi kewajiban yang

\footnotetext{
${ }^{14}$ Buku Tanya-Jawab Hukum Islam, Abdulaziz Mohammad Alsalman, bag. 2 hlm. 114-115

${ }^{15}$ Ensiklopedia, vol. 45 hlm. 195
} 
diberikan suami kepada istri, suatu perkara yang menjadi keuntungan finansial bagi suami dan suami akan berhenti memberi istrinya nafkah dan uang belanja pada umumnya, suatu perkara yang menimbulkan konflik kepentingan.

Ketetapan hukum Islam memasukkan istri sebagai salah satu golongan yang tidak boleh diberi Zakat oleh sang pembayar Zakat. Suami tidak boleh memberikan Zakat Syariah kepada istrinya. Ibnu Qodamah mengatakan ini adalah kesepakatan umum diantara para cendekiawan Muslim. Mazhab Hanafi menyebutkan hal ini tidak diperbolehkan karena manfaatnya sama, namun sebagian besar cendekiawan Muslim berpendapat bahwa nafkah dan uang belanja istri merupakan kewajiban suami secara hukum, maka pemberian Zakat kepadanya dianggap seperti membayar Zakat pada diri sendiri jadi tidak diperbolehkan memberinya Zakat untuk digunakan sendiri. Mazhab Maliki menyatakan boleh memberikan Zakat pada istri dengan syarat ia harus membelanjakannya untuk orang lain namun mazhab Syafii memiliki pendapat lain yang serupa yang menyatakan bahwa suami tidak boleh memberi istrinya Zakat sebagai orang miskin dan membutuhkan, sedangkan diperbolehkan memberi Zakat dalam kapasitasnya dalam golongan lain yang berhak menerima Zakat. ${ }^{16}$

\section{c. Pembayaran Zakat dari Istri Kepada Suami}

Banyak pendapat yang menyatakan ya dan tidak terhadap pemberian Zakat dari istri kepada suami, namun jelas bagi Saya tidak ada salahnya bagi istri memberi suaminya Zakat jika ia termasuk salah satu golongan yang berhak menerima Zakat atas dua pertimbangan contoh dan petunjuk berdasarkan sabda Nabi. Pertimbanganya adalah wanita tidak wajib secara hukum menafkahi suaminya dan bahkan jika ia kaya pun suaminya wajib menafkahinya. Maka, jika sang istri memberi Zakat pada suaminya ia tidak akan diuntungkan dari hilangnya hak wajib seperti nafkah dari suaminya

${ }^{16}$ Ensiklopedia, vol. 23 hlm. 327 
dan oleh karena itu tidak ada konflik kepentingan diantara dua hal penting tersebut.

Contoh berdasarkan sabda Nabi yang diriwayatkan oleh Bukhari menyatakan bahwa Nabi s.a.w. mengizinkan seorang wanita untuk memberi sedekah (Zakat) kepada suaminya yang miskin. Abu Sa'id (r.a.) meriwayatkan, “Zainab istri Ibnu Mas'ud mendatangi dan berkata pada Nabi: 'Ya Rasulullah (s.a.w.)! Engkau telah memerintahkan untuk bersedekah. Aku mempunyai perhiasan dan aku ingin memerikannya sebagai sedekah, tapi Ibnu Mas'ud menyatakan ia dan anaknya adalah yang berhak menerima sedekahku. Mereka lebih berhak dibanding yang lain.' Rasulullah s.a.w. bersabda, 'Ibnu Mas'ud benar. Suami dan anakmu lebih berhak $^{17}$."

\section{d. Pembayaran Zakat kepada Orang yang Berhutang}

Mengenai pemberian Zakat kepada orang yang berhutang kepadanya, sebetulnya berarti bahwa ia memberi Zakat pada orang yang nantinya mengembalikan Zakat itu sebagai pembayaran hutang. Hal ini berarti bahwa sebenarnya ia belum membayar Zakat, maka tindakan ini tidak dapat diterima dalam Syariat Islam. Jika yang membayar Zakat berniat dengan Zakat itu ia mendapatkan kembali uangnya atau pembayaran hutang dari debiturnya, tindakan ini tidak diperbolehkan. Ibnu Al-Qayem mengatakan tindakan seperti itu dianggap sebagai salah satu muslihat yang tidak dibenarkan. Ia mengambil contoh apabila seseorang memiliki piutang pada orang yang pailit atau sudah kehilangan harapan akan pengembalian uangnya, sehingga ia menganggap hutang ini sebagai Zakat sampai orang yang berhutang itu mampu mengembalikan uangnya pada orang yang memberi piutang (pemberi Zakat) dan membayar hutang kepadanya. Ini merupakan trik apakah ia memberi Zakat dengan syarat membayar hutang kepadanya atau tidak dan tindakan ini tidak akan membebaskan ia dari

${ }^{17}$ Sahih Bukhari, Muhammad Ibnu Ismail Albukhari, hadits no. 1462 
kewajiban membayar Zakat dan tidak akan dianggap sebagai pembayaran Zakat meskipun ia membebaskan hutangnya pada siapapun yang berhutang dan menganggap ini sebagai bagian dari Zakat yang ia tentukan ${ }^{18}$

Mohana berkata Aku bertanya pada Abu Abdullah ... Disampaikan padanya. Bagamana jika ia memberikan (Zakat) pada yang berhutang kepadanya dan orang itu memberikannya kembali? Ia menjawab Aku tidak suka karena ini adalah tindakan licik. Lalu mereka bertanya jika debitur meminjam uang dari kreditur yang menganggapnya sebagai Zakat yang ditentukan, namun debitur mengembalikan kepadanya sebagai pembayaran hutang. Ia mengatakan tindakan ini seperti ini bertujuan agar ia mendapatkan kembali uangnya, dan ini tidak diperbolehkan. ${ }^{19}$

Pendapat bahwa pemberian Zakat kepada orang yang berhutang diperbolehkan selama ia tidak bermaksud dengan Zakat itu mendapatkan kembali uangnya karena Zakat merupakan hak Allah maka tidak boleh dibayarkan demi keuntungan pribadi dan tidak boleh menganggap piutangnya sebagai Zakat karena ia diperintahkan dan tindakan demikian itu berarti menghindari pembayaran Zakat. Sehubungan dengan hal di atas, terlihat adanya aplikasi praktis dari konflik kepentingan dalam ketetapan hukum Syariat Islam mengenai kewajiban pembayaran Zakat. Ini adalah bukti bahwa sumber asas konflik kepentingan kembali kepada Syariat Islam.

\section{Konflik Kepentingan Dalam Preemsi}

Preemsi maksudnya seseorang menggunakan haknya untuk membeli sesuatu sebelum orang lain, dengan harga yang sama, karena prioritasnya dan memiliki uang muka pembelian diatas pembeli lain karena kemungkinan adanya kerugian yang menimpanya akibat dari penjualan tersebut. Umumnya, perantara dagang adalah pemilik uang yang sama, seperti ahli waris yang sah atau mitra dalam perusahaan atau tetangganya.

${ }^{18}$ Buku Tanya-Jawab Hukum Islam, hal. 111 bag. 2

${ }^{19}$ Buku Al-Mughni, bag. 2 hal. 494 
Syariat telah memberikan tetangga hak preemptif (hak membeli terlebih dahulu) atas rumah yang bersinggungan dengannya jika ia ingin menjual rumahnya. Mengenai mitra keuangan, seperti ahli waris yang sah, jika salah satu ahli waris ingin mengambil, meminta ahli waris lain untuk memberikan bagiannya dari harta peninggalan tersebut, dalam properti misalnya, ahli waris lain akan memiliki hak prioritas untuk membeli properti dari harta peninggalannya itu, mencabut keanggotaan sebagai ahli waris yang sah. Berkenaan dengan mitra dalam perusahaan, prioritas pembelian saham yang ingin dijual atau diserahkan oleh salah satu mitra, harus diberikan kepada para mitra lainnya kecuali mereka merelakan haknya untk membeli saham tersebut.

Dalam beberapa kasus, hak preemtif mungkin dapat dihilangkan dan tidak dapat langsung digunakan sebagai dampak asas konflik kepentingan sebagaimana disebutkan dalam pendapat hukum oleh Saleem Rustom Baz, yang menyatakan:

Jika seseorang yang memiliki hak preemptif (hak membeli terlebih dahulu) merupakan penerima kuasa dari pihak penjual, ia tidak akan memiliki hak ini dalam warisan harta tidak bergerak, karena dalam hal ini ia akan dianggap mencoba untuk melanggar atau membatalkan apa yang sudah ia tuntaskan. $^{20}$

Kalimat "mencoba" untuk melanggar atau membatalkan apa yang sudah ia tuntaskan" tidak akurat namun merupakan alasan yang tepat bahwa ia mengetahui betul maksud pihak penjual menjual harta warisan tidak bergerak dan ia memiliki hak membeli lebih dahulu atas kepemilikan harta dalam kapastasnya sebagai tetangga namun tidak menggunakan hak preemptifnya dengan cara yang mengakibatkan kehilangan hak tersebut karena tidak menggunakan hak itu sesegera mungkin tanpa ditunda.

Selanjutnya, ada alasan lain yang selaras dengan penjelasan diatas yaitu bahwa transaksi penjualan dianggap mengikat, bukan pilihan, kontrak,

${ }^{20}$ Buku Sharhul Majalat Alahkam Aladliyah, Saleem Rustom Baz, Pasal 1024 hal. 494 
dan maka dari itu kontrak penjualan yang disebutkan diatas akan berlaku setelah ditandatangani dan mengikat kepada semua pihak (termasuk pihak yang memiliki hak membeli terlebih dahulu) dan oleh karena itu, komitmen ini tidak dapat dibatalkan. Asas ini akan dterapkan terhadap seluruh mitra kontraktor atau juru kuasa mereka (penerima kuasa).

Ibnu Qudamah menyebutkan:

Jika sang perantara menjadi penerima kuasa dalam transaksi jual beli, ia tidak akan kehilangan hak preemptifnya kalaupun ia bertindak atas nama pembeli. (Diriwayatkan oleh Al-Sharif dan Abu Al-Khatab dan juga sesuai dengan pendapat sebagian dari mazhab Syafii).

Al-Qadhi dan sebagian cendekiawan Syafii mengatakan: Jika ia bertindak sebagai penerima kuasa dari pihak penjual, ia tidak memiliki hak membeli lebih dahulu karena ia akan dituduh menjual dengan mengurangi harga dan menguasai harta tersebut. Menurut para ahli hukum, penerima kuasa dari pihak pembeli, tidak memiliki hak membeli terlebih dahulu (preemptif) berdasarkan aturan hukumnya bahwa harta akan dipindah tangankan kepada penerima kuasa itu, maka tidak diperbolehkan baginya. ${ }^{21}$

Meskipun terdapat perbedaan pendapat diantara pakar hukum Islam atas hilangnya hak preemtif, jika orang yang memiliki hak itu merupakan penerima kuasa dari pihak penjual atau pembeli, atau bukan keduanya. Dalam pandangan saya, Tuhan Yang Maha Kuasa (Allah) yang mengetahui perantara tidak diperbolehkan menggunakan hak preemtif baik ia merupakan penerima kuasa dari pihak penjual atau pembeli dengan alasan, sebagaimana sudah Saya sebutkan bahwa ia mengetahui tujuan penjualan dan diamnya akan hal yang sama dan kemudian ia menuntaskan proses penjualan/pembelian, akan menyebabkan ia kehilangan hak preemptifnya karena penggunaan hak ini harus dilakukan dengan segera dan tidak ditunda-tunda serta tidak akan terjadi pada penerima kuasa dari pihak-pihak yang disebutkan di atas. Disi lain, menurut pendapat berbagai pakar hukum

${ }^{21}$ Buku Al-Mughni, vol. 5 hal. 380 
diatas penerima kuasa dari pihak penjual tidak boleh memanfaatkan hak preemtif karena ia akan dituduh menjual dengan harga rendah agar dapat ia kuasai sendiri, berlawanan dengan penerima kuasa dari pihak pembeli.

Pendapat ini dianggap sebagai penerapan langsung dari asas konflik kepentingan karena adanya duplikasi peran yang diasumsikan pada pihak penerima kuasa dalam kapasitasnya sebagai penerima kuasa dari pihak penjual dan sebagai perantara. Maka, karena ia memiliki hak preemtif dan bermaksud menggunakan hak tersebut menjadikan ia bersikap masa bodoh untuk menjualnya pada harga yang menguntungkan atau harga yang setara karena ia akan membeli untuk dirinya sendiri. Maka, timbul kecurigaan pada satu sisi dan konflik kepentingan di sisi lain. Oleh karena itu, seperti yang Saya sebutkan, ada pendapat yang lebih cenderung kepada menghilangkan hak preemtif pada penerima kuasa dari pihak penjual.

\section{Konflik Kepentingan Dalam Masalah Perwakilan}

Kewenangan yang ditunjukkan dalam surat kuasa menciptakan situasi hukum dimana penerima kuasa mewakili pemberi kuasa yang memberinya kewenangan berdasarkan isi dari surat kuasa tersebut, baik yang merupakan perwakilan umum maupun perwakilan khusus (surat kuasa). Penempatan pihak penerima kuasa dapat termasuk pembelian, penjualan, pengangkatan, atau suksesi. Penerima kuasa harus berkomitmen terhadap kepentingan pemberi kuasa sepanjang penerima kuasa tidak melampaui ruang lingkup yang diwakilinya. Oleh karena itu, penerima kuasa memainkan peran ganda, pertama yaitu ia bekerja sebagai perwakilan dari pemberi kuasa dan yang kedua mewakili dirinya secara pribadi. Maka penempatan apapun yang dibuat oleh penerima kuasa yang mengatasnamakan pihak pemberi kuasa harus menunjukkan dirinya sebagai penerima kuasa, bukan bertindak untuk dirinya sendiri.

Karakter ganda dari penerima kuasa menciptakan situasi yang memungkinkan timbulnya konflik kepentingan jika pihak penerima kuasa diberi kewenangan untuk menjual harta milik pemberi kuasa dan kemudian ia 
memilikinya untuk dirinya sendiri dalam kapasitasnya sebagai pembeli dari barang yang diperdagangkan itu. Umumnya, tindakan seperti itu tidak diperbolehkan dalam sebagaian besar ketentuan dan ketetapan hukum Islam, hal ini juga dilarang dalam legislasi modern.

\section{PENUTUP}

\section{Simpulan}

Simpulan berdasarkan penjelasan di atas, jelas bahwa konflik kepentingan merupakan salah satu asas terpenting dalam hukum modern yang sering kita dengar mengenai aplikasinya pada berbagai bidang, seperti bidang ekonomi dan administratif. Setelah mengkaji dengan saksama dan meneliti lebih dalam kesimpulan yang bisa ditarik bahwa ini adalah asas penting. Bahwa asas ini berasal dan kembali kepada ketentuan Syariat karena ketetapan hukum Islam lama dipenuhi oleh ketentuan yang ketat dan akurat yang menentukan situasi konflik kepentingan dalam berbagai bidang, seperti jual-beli, sumpah, zakat, preemsi, dan perwakilan.

\section{Saran}

Setelah semua kasus negatif dan situasi konflik kepentingan ditentukan, berbagai ketentuan Fikih (ketetapan hukum) Islam dibuat guna mencegah konflik kepentingan tersebut dan melarangnya serta membatalkan tindakan dan penempatan yang mengekspresikan suatu kasus konflik kepentingan. Ini merupakan penelitian singkat. Oleh karena itu sebaiknya bagi para peneliti hukum Islam untuk lebih banyak mengembangkan asas-asas dalam hukum dan fiqih Islam untuk menarik lebih banyak hasil dan kesimpulan pentingidi masa yang akan datang. 


\section{DAFTAR PUSTAKA}

\section{A. Buku}

Adrian Sutedi, Hukum Keuangan Negara, Sinar Grafika, Jakarta, 2012

C.S.T. Kansil dan Christine Kansil, Hukum Keuangan dan Perbendaharaan Negara, Pradnya Paramita, Jakarta, 2008.

Chaniur Arrasjid, Hukum Pidana Perbankan, Sinar Grafika, Jakarta, 2013.

Ibnu Qudamah. Al-Mughni, Mekkah, 2013.

Ensiklopedia Ketetapan Hukum, Kementrian Wakaf Kuwait.

Ahmad bin Abdullah Al-Qari

Muhammad Ismail Albukhari, Shahih Bukhari Albukhari,

Saleem Rustom Baz, Sharhul Majalat Alahkam Aladliyah.

\section{B. Jurnal}

Abdulaziz Alsalman, Ketetapan Hukum Syariah (Majalat Alahkam Alshar'iyah), Jurnal Tanya-Jawab Hukum Islam.

Ainun Najib, Kepastian Hukum Eksekusi dan Pembatalan Putusan Arbitrase Syariah dalam Perspektif Politik Hukum, Jurnal Ius Quia Iustum, Vol 26 No 2, 2019

Dudi Badruzaman, Hubungan Antara Moral dengan Hukum, Jurnal Syiar Hukum, Vol 16 No 1, 2017.

Hermansyah, Impementasi Bagi Hasil Dengan Prinsip Mudharabah Pada Bank Syariah di Indonesia Dihubungkan dengan Fatwa DSN No : 15/DS-MUI/IX/2000, Jurnal Mimbar Justitia, Vol 4 No 1, 2018.

Ira Puspitasari, Anaisis Praktik Etika Bisnis Syariah (Studi Kasus Pasar Leuwiliyang), Jurnal Amwaluna, Vol 3 No 1 Januari 2019.

Suparman Marzuki, Politik Hukum Hak Asasi Manusia Tentang Kebebsan Beragama Pasca Orde Baru, Jurnal Ius Quia Iustum, Vol 26 No 2, 2019. 